\title{
マウスにおける放射性ルテニウム $\left({ }^{106} \mathrm{Ru}\right)$ の 臓器內分布および排泄
}

\author{
西連寺永康 \\ (日本大学荤学部放射線学教室・放射性同位元素研究室) \\ (昭和 35 年 10 月 20 日 受理)
}

\section{はしがき}

原子力の利用開発の進展に伴い, 原子炉から今 後ますます多量に生ずる核分裂生成物の廃棄処理 は, 人類の生活環境への污染ということと関連し て極めて重要な問題であり，それらの物質が体内 に摂取された場合の影響についての基礎的な資料 をえておくことが現在必要である。

核分裂生成物の生体内における分布や排泄に関 しては, すでに J.G. Hamilton や K. G. Scott ら 1) 8)の一連の研究がみられ，またわが国におい ても，いわゆる「ビキニの灰」事件や核爆発実験 にともなう放射性降下物の影響などと関連して, 吉沢 $ら^{9)}$, 入江ら ${ }^{10)}$, 吉川ら ${ }^{11)}$ および宮川 ${ }^{12)} ら に$ よる研究が発表されている。さらに, 核分裂生成 物中の特定のもの一一とえば ${ }^{90} \mathrm{Sr}$ や ${ }^{137} \mathrm{Cs}-$ についての研究は非常に多く, その研究規模も全 世界的なものとなってきている。けれどもそのほ かの核種についての検討をおこなったものは割合 に少ない。

ルテニウム $\left({ }_{44} \mathrm{Ru}\right)$ は， ウランまたはプルトニ ウムなどの核分裂によって放射性の ${ }^{103} \mathrm{Ru},{ }^{106} \mathrm{Ru}$ およびそのほかの核種を生ずるが，その場合の収 率は比較的大きく $3 \sim 5 \%$ におよんでいる ${ }^{13)}$ 。ま た, その半減期も長く, 核分裂生成物による放射 能強度に対する割合は, 核分裂後の 1 力月から数 年間にわたって, 数パーセントにも達している ${ }^{14) 。 ~}$ その放射化学的なデータを第 1 表に示したが， ${ }^{103} \mathrm{Ru}$ は強い $\beta, \gamma$ 放射体であり,また, ${ }^{106} \mathrm{Ru}$ は
その娘核種である ${ }^{106} \mathrm{Rh}$ がはなはだ強い $\beta, \gamma$ 放 射体であるから，このような核種が生体内にはい った場合に強い放射線損傷を惹き起こすことが当 然予想される。そこでこの元素が生体内にとり込 まれた場合の臟器内分布を知り, 問題となる臟器 (critical organ) を明らかにし，また排泄の状態 などについて検討しておく必要があると考える。

現在までの放射性ルテニウムの動物体内代謝に 関する研究は比較的その数が少なく, K. G. Scott $ら^{4)}$, R. C. Thompson ら ${ }^{15)}$, 吉川ら ${ }^{11)}$ がラットあ るいはマウスの腹腔内投与の場合について， M. H. Weeks ら ${ }^{16)}$, K. G. Scott $ら^{4)}$ および L. N. Burykina $^{17)}$ が経口投与の場合について，おなじ くK. G. Scott ら ${ }^{4}$, L. N. Burykin7 ${ }^{17)}$ がそれぞれ 筋肉内注射抢よび皮下注射の場合について，また

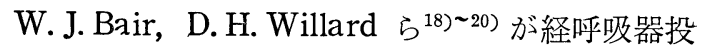
与の場合についての体内分布と排泄の状態を報告 しているに過ぎなく*，えられた結果は各実験者 によりかなりの差違がある。たとえば, 腹腔内投 与の体内分布について, Scott ら ${ }^{4)}$, Thompson $ら^{15)}$ が腎臟への集積が多く骨に選択的に沈着する ことはみとめられないとしているが，吉川ら ${ }^{11)}$ 同期間の実験で歯および骨が最大であり，次いで 腎臟に多くみられるとしているし， Scott ら

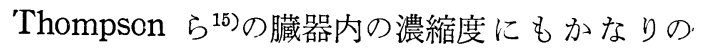

* このほかに J. G. Hamilton の報文の3),44,6)・9)中に ルテニウムに関するデータが記載されて指り，よ了 引用されるが，実験方法に関する記述がまったく久 けている。 
Table 1 Radioactive ruthenium in fission products

\begin{tabular}{|c|c|c|c|c|c|c|}
\hline \multicolumn{4}{|c|}{ Parent } & \multicolumn{3}{|r|}{ Daughter } \\
\hline Nuclide & $\begin{array}{l}\text { Fission* } \\
\text { yield }(\%)\end{array}$ & $\begin{array}{l}\text { Half- } \dagger \\
\text { life }\end{array}$ & $\begin{array}{l}\text { Type of decay and energy } \dagger \\
\text { of radiation }(\mathrm{MeV})\end{array}$ & Nuclide & $\begin{array}{l}\text { Half- } \dagger \\
\text { life }\end{array}$ & $\begin{array}{l}\text { Type of decay and energy } \dagger \\
\text { of radiation }(\mathrm{MeV})\end{array}$ \\
\hline \multirow{2}{*}{${ }^{103} \mathrm{Ru}$} & \multirow{2}{*}{3.0} & \multirow{2}{*}{$39.8 \mathrm{~d}$} & \multirow{2}{*}{$\begin{array}{l}\beta-; 0.119,0.227, \text { others } \\
r ; 0.61,0.495, \text { others }\end{array}\left(\coprod_{5 \%}^{103 \mathrm{~m} R \mathrm{Rh}}{ }_{1}^{103}{ }^{103}\right)$} & ${ }^{103 m} \mathrm{Rh}$ & $57 \mathrm{~m}$ & $\mathrm{IT}-(\gamma) ; 0.0400\left(\rightarrow^{103} \mathrm{Rh}\right)$ \\
\hline & & & & ${ }^{103} \mathrm{Rh}$ & Stable & \\
\hline \multirow{2}{*}{${ }^{105} \mathrm{Ru}$} & \multirow{2}{*}{0.9} & \multirow{2}{*}{$4.5 \mathrm{~h}$} & \multirow{2}{*}{$\begin{array}{l}\beta^{-} ; 1.15 \\
\gamma ; 0.726\end{array}\left(\rightarrow \rightarrow^{\left.105 \mathrm{~m} R h \rightarrow{ }^{105} \mathrm{Rh}\right)}\right.$} & ${ }^{105} \mathrm{Rh}$ & $45 \mathrm{~S}$ & $\mathrm{ITe}^{-} \gamma ; 0.130$ \\
\hline & & & & ${ }^{105} \mathrm{Rh}$ & $36.5 \mathrm{~h}$ & $\mid \begin{array}{l}\beta-; 0.570,0.25 \\
\gamma ; 0.320\end{array}\left(\rightarrow^{105} \mathrm{Pd}\right.$, stable $)$ \\
\hline${ }^{106} \mathrm{Ru}$ & 0.38 & $1.00 \mathrm{y}$ & $\begin{array}{lc}\beta-; & 0.0392 \\
\gamma ; & \text { no }\end{array} \quad\left(\rightarrow{ }^{106} \mathrm{Ru}\right)$ & ${ }^{106} \mathrm{Rh}$ & $30 \mathrm{~S}$ & $\begin{array}{r}\beta-; 3.53,3.1,2.44,2.0, \\
\gamma ; 0.51,0.624,0.87, \text { others } \\
\left(\rightarrow{ }^{106} \mathrm{Pd} \text { satble }\right)\end{array}$ \\
\hline${ }^{107} \mathrm{Ru}$ & $\longrightarrow$ & $4 \mathrm{~m}$ & & & & \\
\hline${ }^{108} \mathrm{Ru}$ & - & $\sim 4 \mathrm{~m}$ & & & & \\
\hline
\end{tabular}

$\dagger$ These values are borrowed from D. Strominger, J. M. Hollander, and G. T.Seaborg: “Table of Isotopes ", Rev. Mod. Phys., 30, 679, (1958)

* From S. Katcoff ; Nucleonics, 16, 78 (1958)

差がある。このような点からもルテニウムの代謝 について再検討し，より新しい生物学的データを えておくことが必要となる。

また，同一の元素でも投与される場合の形が異 なればそののちの代謝にも違いが出ることが考え られるが，現在までのこのような実験の一般的な 傾向として投与時の放射性物質の形に対する考慮 が厳密に払われているものが少ないように見受け られる。著者は生体内の核分裂生成物の分離分析 法について検討して ${ }^{21,22}$ 陽イオン交換樹脂を使用 しての分属分離法が操作の簡便さと実験結果の再 現性の上から適当であることを知ったが*，その さい，木村ら ${ }^{23)}$ ，塩川ら ${ }^{24)}$ も指摘しているように 陰イオン部に流出するはずのルテニウムの挙動が 試料の前処理の方法によって幾分異なり，その一 部が陽イオン部にも流出することを認めた**。こ れはルテニウムの化学的性質がはなはだ複雑なこ

*これについては木村・池田らの報告（本誌， 6, 85, 1957) がある。

** 著者が ${ }^{106} \mathrm{Ru}$ をトレーサーとして据こなった実 験では，ある場合にはアルカリ土類の部分までの 各区分に分散流出することが認められた。
とに起因するもので，動物体内に投与するさいト レーサー溶液中におけるルテニウムの状態につい ても当然これを明瞭にしてから使用する必要があ ると考える。

著者は以上の観点から，投与時のトレーサー溶 液中のルテニウムの化学的状態を明確に規定し, その体内分布および排泄の状態を時間的に追跡 し，現在までの研究と比較し，ルテニウムの場合 に問題とすべき臟器を知り，またその変動を解析 して生物学的半減期および有効半減期の検討をお こない，ルテニウムの生体への影響を明らかにす るための一資料とする目的で本実験をおこなっ た。同時にまた，投与されたルテニウムと血液と の結合状態についても検討を加えた。

\section{実 験 方 法}

1）ルテニウム・トレーサー溶液の調製をルテ ニウムの溶存状態の検討

英国から輸入した ${ }^{106} \mathrm{Ru}$ 原液*を $0.9 \%$ 生理食

* Amersham 製, $\mathrm{RuCl}_{3}$ in $5.5 \mathrm{~N} \mathrm{HCl}$ soln; purity $99 \%\left({ }^{106 \mathrm{Ru}}+{ }^{106} \mathrm{Rh}\right)$, これは別と $\gamma$ 線スペクトロメ トシーによっても確かめてある。 
塩水でうすめ, その放射能量が $2.8 \mu \mathrm{c} / \mathrm{m} l$ のもの を調製した。

ルテニウムは, 溶液内における化学的性状が複 雑であり, 種々の酸化状態のイオン種の共存が考 えられる。そこで, 本実験に使用するトレーサー 溶液中のルテニウムの溶存状態を明らかにしてお くため, 口紙電気泳動法による検討を扢こないイ オン種を決定した。

$\mathrm{HAc}-\mathrm{NaAc}$ 緩衝液 $(\mathrm{pH}=4.9)$ を用い, 東洋口 紙 No. 50 に ${ }^{106} \mathrm{Ru}$ 原液および $0.9 \%$ 生理食塩水 にうすめたものおの㧍の $0.1 \mathrm{ml}$ をつけて, クロ ルベンゼン中に浸し， $400 \mathrm{~V}, 10 \mathrm{~mA}$ の通電で 3 時間泳動させた。その結果は第 1 図に示めすよう に, $-2,-1$ および 0 価のイオン種の存在が明ら

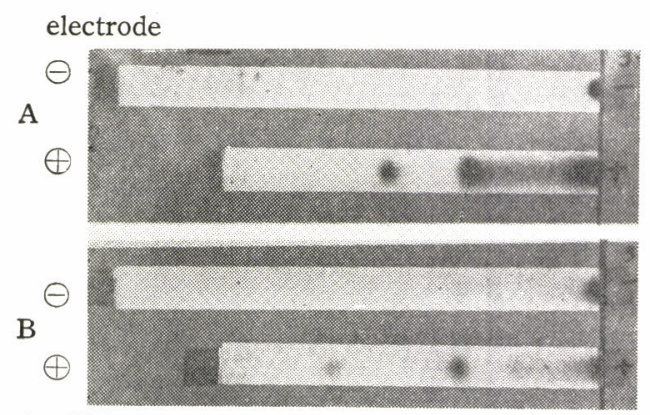

A: ${ }^{106} \mathrm{Ru}$ in stock solution

B: ${ }^{106} \mathrm{Ru}$ in $0.9 \% \mathrm{NaCl}$ solution

Conditions: HAc-NaAc buffer $(\mathrm{pH}=4.9)$ $400 \mathrm{~V}, 10 \mathrm{~mA}, 3 \mathrm{hrs}$.

Fig. 1 Autoradiogram of paper electrophoresis for ruthenium chloride
かである。また， 口紙を $0.5 \mathrm{~cm}$ 間隔で切断して 放射能を計数した結果を第 2 表に示したが， +1 および +2 価のイオン種の存在も否定できない。 3 価のルテニウムは溶液中においての配位数が 6 であることが知られているが25)，この実験の結果 からこのトレーサー溶液中には, $\left[\mathrm{RuCl}_{3}\left(\mathrm{H}_{2} \mathrm{O}\right)_{3}\right]^{\circ}$, $\left[\mathrm{RuCl}_{4}\left(\mathrm{H}_{2} \mathrm{O}\right)_{2}\right]^{-1},\left[\mathrm{RuCl}_{5}\left(\mathrm{H}_{2} \mathrm{O}\right)\right]^{-2}$ などが存在し ているものと推定しうる。また, 原液中の溶存状 態と $0.9 \%$ 食塩水中の溶存状態にも大きな変化は ない。松浦ら ${ }^{26)}$ は ${ }^{106} \mathrm{RuCl}_{3}$ 溶液について $300 \mathrm{~V}$, 100 分の口紙電気泳動を $\mathrm{HCl}-\mathrm{KCl}$ 緩衝液 $(\mathrm{pH}=$ 1.6) で打こなって， $\mathrm{Ru}$ (III) およで〔 $\mathrm{RuCl}_{4}$ $\left.\left(\mathrm{H}_{2} \mathrm{O}\right)_{2}\right]^{-1}$ の存在をみとめているが, 一2 価のイオ ン種は確認していない。これは緩衝液, 原液の規 定度などの相違によるものかも知れない。

さらに, キャリヤーフリーの放射性物質が溶液 中でラジオコロイドを形成するという報告 ${ }^{27) か ゙ あ ~}$ るが，使用したトレーサー溶液について，遠心分 離法による検出を試みたところでは，ルテニウム のラジオコロイドの生成はみとめられなかった。

2) 実験動物,トレーサーの投与および試料の 採取。

上記のルテニウム食塩水溶液の $0.2 \mathrm{~m} l$ ずつ* を体重約 $13 \sim 15 \mathrm{~g}$ 程度の DD 系マウスの腹腔 内に注射後, 1 群 3 ないし 7 匹としてオリエンタ 儿製固型餌料 MF および水道水で飼育し, 実験 開始後一定期間を経るごと（1 日，2 日，3 日，

* $\quad 0.48 \mu \mathrm{c} \quad{ }^{106} \mathrm{Ru}+{ }^{106} \mathrm{Rh} / 0.2 \mathrm{ml} /$ animal.

Table 2 Valency states of ruthenium in the tracer solution

\begin{tabular}{|c|c|c|c|c|c|c|}
\hline \multicolumn{2}{|c|}{$\begin{array}{l}\text { Conceivable ion } \\
\text { species }\end{array}$} & \multirow{2}{*}{$\begin{array}{c}{\left[\mathrm{RuCl}_{5}\left(\mathrm{H}_{2} \mathrm{O}\right)\right]^{-2}} \\
-2\end{array}$} & \multirow{2}{*}{$\frac{\left[\mathrm{RuCl}_{4}\left(\mathrm{H}_{2} \mathrm{O}\right)_{2}\right]^{-1}}{-1}$} & \multicolumn{2}{|l|}{$\left[\mathrm{RuCl}_{3}\left(\mathrm{H}_{2} \mathrm{O}\right)_{3}\right]^{0}$} & \multirow{2}{*}{$\frac{\left[\mathrm{RuCl}\left(\mathrm{H}_{2} \mathrm{O}\right)_{3}\right]+2}{+2}$} \\
\hline Sample & Valency & & & 0 & +1 & \\
\hline${ }^{106} \mathrm{RuCl}_{3}$ in & $\begin{array}{l}\text { relative } \\
\text { value }\end{array}$ & 0.118 & 0.384 & 1 & 0.009 & 0.02 \\
\hline stock soln. & $\%$ & 7.79 & 25.34 & 66.12 & 0.60 & 0.13 \\
\hline${ }^{105} \mathrm{RuCl}_{3}$ in & $\begin{array}{l}\text { relative } \\
\text { value }\end{array}$ & 0.137 & 0.340 & 1. & 0.006 & 0.002 \\
\hline $0.9 \% \mathrm{NaCl}$ soln. & $\%$ & 9.23 & 22.910 & 67.34 & 0.41 & 0.10 \\
\hline
\end{tabular}


5 日， 6 日， 8 日， 10 日， 18 日， 28 日， 37 日， 50 日) に犠性として実験試料を得た。一部のもの は，特別に製作した飼育箱中で飼育して毎日の糞 および尿（口紙によって集める）をそれぞれ別個 に採取し，ルテニウムの排泄をしらべることにし た。実験に使用した動物数は，雄 31 匹，雌 17 匹，合計 48 匹であった。

ほかに，5匹のマウスに同じくルテニウム溶液 を注射し，1日後に断頭採血をおこなっで，投 与されたルテニウムと血液との結合状態を検討す るための試料とした。

3) 放射能測定

採取した各臟器試料はただちに科量し，のちガ ラス製試料皿に入れ，濃硝酸の少量を加えて赤外 線ランプ下で徐々に分解し乾固させて均一な測定 用試料を調製した**。組織量の多いものについて は,この操作を 2 ないし 3 回繰り返して均一に試 料血内に分散させた。

尿および糞試料については，その量を減ずるた め, HWO の分析のための放射化学専門委員会の 提案している生体試料中のルテニウム分析法 ${ }^{28)} に$ したがって $450^{\circ} \mathrm{C}$ の電気炉内での灰化をおこ なったのち全量を注意深く試料皿に移して放射能 測定に供した。この灰化法では，炉の温度が $450^{\circ} \mathrm{C} \sim 500^{\circ} \mathrm{C}$ ではルテニウムの損失は 10 時間 後に約 $10 \%, 550^{\circ} \mathrm{C} \sim 600^{\circ} \mathrm{C}$ では 3 時間で約 $9 \%$ であった。これはルテニウムが四酸化物となって 揮発逸散するためと考らえれる***。

放射能の計測には科研製 100 進型 G-M 計数

* ヘパリンナトリウム塩溶液の少量を加えて血 液の防㠜固を括こなった。

**乙の操作によってほ組織中の有機物は完全に

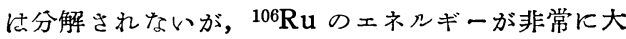
きいので試料の自己吸収による誤差仙考慮しなく てもよい。また操作の途中にルテニウムの逸出が 起こらないことはすでに確かめてある22)。

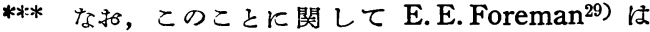
$500^{\circ} \mathrm{C}$ 以下では 24 時間加熱後でも回収率は $100 \%$ そし, L. N. Burykina ${ }^{17)}$ は $500^{\circ} \mathrm{C}$ て 3 時間後に $19.2 \%, 6$ 時間後に $41 \%$ のルテニウムの損失があ るとしている。
装置（端空型，マイカ空の厚さ $1.2 \mathrm{mg} / \mathrm{cm}$ ) を用 いた。この装置による ${ }^{106} \mathrm{Ru}+{ }^{106} \mathrm{Rh}$ の計数効率 は $17.0 \%$ である*。

ルテニウムとの結合状態を知るための血液試料 は，遠心分離して血漿と有形成分とに分け，それ ぞれ東芝製ウェル型シンチレーションカウンター 〔NaI (Tl) 結晶, $1 \frac{3^{\prime \prime}}{4} \times 2^{\prime \prime} 〕$ でガンマ線計数をお こなった。

4）血漿の口紙電気泳動

分離した血漿部分について，蛋白とルテニウム との結合状態を知るためにロ紙電気泳動をおこな った。ベロナール緩衝液 $(\mathrm{pH}=8.6, \mu=0.05)$ を使 用し東洋口紙 No. $51\left(16 \times 12 \mathrm{~cm}^{2}\right)$ に試料をつけ $260 \mathrm{~V}, 6 \mathrm{~mA}$ ，常温で 5.5 時間の泳動をおこなっ た。泳動後口紙を $110^{\circ} \mathrm{C}$ の空気浴中で乾燥 $\mathrm{Fuji}$ $\mathrm{X}$ 線フィルム（メディカル・タイプ）と密着させ 1 カ月後現像しオートラジオグラムを作る。また， マウス血漿と ${ }^{106} \mathrm{Ru}$ とを in vitro に混合し $5^{\circ} \mathrm{C}$ で 1 昼夜保持しておいた試料および注射に使用し たルテニウムのトレーサー溶液についても，同様 の条件でロ紙電気泳動をおこない対照とした。

蛋白の定量は，B. P. B. による染色後キシロー ルによりロ紙を半透明化し島津製微測光度計によ り吸光度を測定し直接定量した。一部の口紙試料 は $0.5 \mathrm{~cm}$ 幅に切断しベータ線計数をおこなって 放射能の分布状態をしらべた。

\section{実験結果および考察}

1）血液内における放射性ルテニウムの存在状 態

体内にはいったルテニウムは血液を介して諸蔵 器に分布してゆくと考えられるが，そのさいの血 液中におけるルテニウムの状態は体液との結合と いう点からもはなはだ興味深い。

前述のようにして遠心分離計数した ${ }^{106} \mathrm{Ru}$ を 含むマウス血液中の血漿と有形成分との放射能を

* 医理学研製 FC-17 型 $4 \pi$ スケーラーで $4 \pi$ 計数 を括こなったものを用いて定めた。 
比較して，血液中に含まれる放射能の大部分（約 93\%）が血漿中に存在し，有形成分中のものの約 13 倍に及ぶことを知った。

口紙電気泳動によって分離した血墏中の蛋白の 分離状態および放射能の分布を第 2 図に示してあ

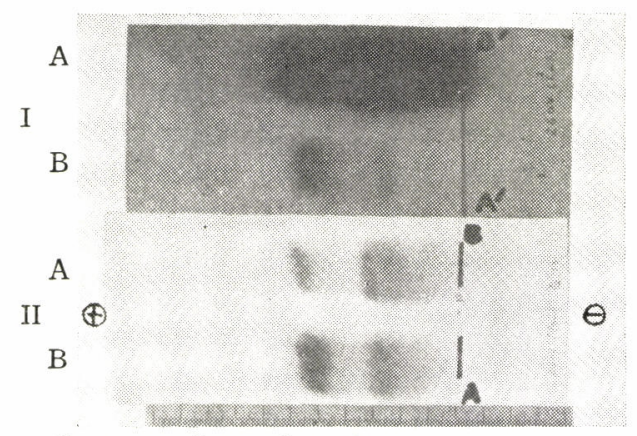

I. paper electrophoresis.

II. Autoradiogram.

A: Blood plasma of the mouse injected ${ }^{106} \mathrm{Ru}$ solution.

B: Blood plasma mixed with ${ }^{106} \mathrm{Ru}$ solution (in vitro)

Conditions: veronal-buffer $(\mathrm{pH}=8.6, \mu=0.05) 26$ $0 \mathrm{~V}, 6 \mathrm{~mA}, 5.5 \mathrm{hrs}$, temp. $25^{\circ} \mathrm{C}, \mathrm{B} . \mathrm{P} . \mathrm{B}$--staining.

Fig. 2 Paper electrophoresis of blood plasma

る。マウス血漿中の蛋白は 2 つ明瞭な画分に分 かれ，それぞれの位置に対応して強い放射能の 存在がみとめられる。また蛋白の細かい画分を吸 光度の測定により定め, 同時にそれらの部分につ いての放射能量を求めたが，アルブミン， $\beta$-グロ ブリンおよび $\gamma$-グロブリンに当ると思われる部 分はそれぞれ全体の $62 \%$ ，24\% および 14\% 程 度の值であった。in vitro に ${ }^{106} \mathrm{Ru}$ を加えた血漿 についてもほぼ同様の結果が得られ，放射能量法

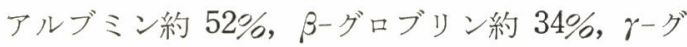
ロブリン約 $14 \%$ であった。また ${ }^{106} \mathrm{Ru}$ 溶液のみ を同一条件で泳動した場合には，その放射能の大 部分が原点にとどまっており，残部の放射能につ いても蛋白の泳動距離とは一致していなかった。 これらのことから，血液中に存在するルテニウム は蛋白と結合して抢り先の状態は in vitro に混 合したものとほぼ同様であると考えられる。 R.
F. Palmer ${ }^{30)}$ はルテニウムを含むラット血漿を同 様のベロナール緩衝液を用い， $5.0 \mathrm{~mA}$ の条件で 16 18 時間泳動し各蛋白分画中の放射能量を測 定して，アルブミン $30 \% ， \alpha_{2}-$ グロブリン $25 \%$ ，

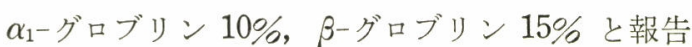
しているが，血漿中の蛋白組成は各動物によって 異なっており尔，また泳動条件などの差もあって おのおのの量を直接対比することはできない。

2) ルテニウム放射能の臟器内分布

実験群ごとの臟器別ルテニウム放射能量を第 3 表にしめした。表中の数值はそれぞれの群の各臓 器の全量中に含まれている放射能の平均を投与量 に対する百分率であらわしたものである*。この 場合, 血液, 筋肉, 骨㧍よび皮膚（毛を含む）に ついては，その全量を採取することができなかっ たので体重に対してそれぞれ $12.5 \%, 45.4 \%, 11.0$ $\%$ および $18.0 \%$ としてその重量在求め, 所要の 百分率を算出した。表中の主要な臟器について経 日変化の状態を第 3 図に示した。

各臓器内に扔ける放射性物質の濃縮度を示すた めに, Quimby ら $^{32}$ ほ吸收率較差 (differential absorption ratio, DAR) なる值を提唱した。筧， 渡辺ら ${ }^{33,34)}$ はこれを桩大して, 相対的比放射能 (relative specific activity) RSA**なる值を用 いているが，これは組織線量の計算にも便利なの でこの值を算出し第 4 表に示した。このうち主要 な臟器についての変化を第 4 図に示した。

臓器全体の放射能量についてみると, 実験の初 期 (10 日目頃まで) に扔いては，血液，骨，筋肉，

* $106 \mathrm{Ru}$ の壊変活測定器の計数效率扔よび物理的 半減期に対する測定なでの経過洔間の割合によっ て補正した。

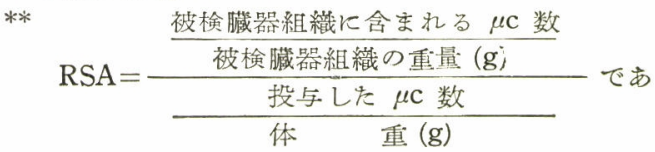
らわされ，との值が 1 のををは注射したとをと 同濃度, それ以上ならば, 濃縮, それ以下では希 釈されて葴器内に存在することを意味する。（筧， 渡辺)。 
Table 3 Ruthenium concentration in tissues following intraperitoneal injection (Expressed as per cent of administered dose)

\begin{tabular}{|l|c|c|c|c|c|c|c|c|c|c|c|}
\hline \multicolumn{1}{|c|}{ Tissue } & $1 \mathrm{~d}$ & $2 \mathrm{~d}$ & $3 \mathrm{~d}$ & $5 \mathrm{~d}$ & $6 \mathrm{~d}$ & $8 \mathrm{~d}$ & $10 \mathrm{~d}$ & $18 \mathrm{~d}$ & $28 \mathrm{~d}$ & $37 \mathrm{~d}$ & $50 \mathrm{~d}$ \\
\hline Blood* & 14.196 & 9.257 & 10.201 & 4.124 & 1.778 & 1.627 & 1.484 & 0.803 & 0.229 & 0.216 & 0.174 \\
Spleen & 1.668 & 2.096 & 1.456 & 1.314 & 1.560 & 0.994 & 0.782 & 0.634 & 0.555 & 0.070 & 0.019 \\
Heart & 0.489 & 0.409 & 0.401 & 0.346 & 0.292 & 0.318 & 0.293 & 0.145 & 0.094 & 0.050 & 0.019 \\
Liver & 11.005 & 14.414 & 11.398 & 10.911 & 11.567 & 9.315 & 9.379 & 6.263 & 3.199 & 2.573 & 1.880 \\
Lung & 1.405 & 1.060 & 1.056 & 0.732 & 0.555 & 0.297 & 0.272 & 0.149 & 0.108 & 0.055 & 0.032 \\
Stomach & 2.341 & 2.923 & 1.436 & 0.730 & 0.668 & 0.589 & 0.428 & 0.233 & 0.142 & 0.048 & 0.023 \\
Pancreas & 0.820 & 1.077 & 1.546 & 0.492 & 0.369 & 0.225 & 0.232 & 0.047 & 0.029 & 0.008 & 0.005 \\
Kidney & 5.927 & 7.495 & 7.962 & 6.678 & 7.490 & 4.672 & 6.109 & 5.163 & 3.655 & 2.405 & 2.188 \\
Adrenals & 0.107 & 0.114 & 0.087 & 0.064 & 0.054 & 0.052 & 0.054 & 0.034 & 0.019 & 0.011 & 0.008 \\
Brain & 0.069 & 0.047 & 0.037 & 0.021 & 0.013 & 0.014 & 0.015 & 0.007 & 0.008 & 0.005 & 0.003 \\
Urinary bladder & 0.310 & 0.621 & 0.906 & 1.255 & 0.457 & 0.203 & 0.121 & 0.091 & 0.048 & 0.014 & 0.011 \\
Bones* & 6.158 & 4.351 & 8.847 & 5.772 & 3.864 & 4.331 & 2.961 & 2.373 & 2.117 & 1.874 & 2.015 \\
Muscles* & 8.468 & 10.802 & 8.083 & 10.922 & 13.899 & 12.562 & 11.567 & 10.401 & 6.131 & 5.291 & 3.857 \\
Skin and Fur* & 5.801 & 6.633 & 5.823 & 6.406 & 7.478 & 7.843 & 8.606 & 7.630 & 9.254 & 5.350 & 3.427 \\
Testes & 1.001 & 1.037 & 0.959 & 1.208 & 0.744 & 0.818 & 0.788 & 0.445 & - & 0.219 & 0.140 \\
Ovaries & 0.135 & 0.126 & 0.093 & - & - & - & 0.043 & - & 0.038 & 0.019 & \\
\hline
\end{tabular}

* For calculation of per cent content per organ 12.5, 45.4, 11.0, 18.0 per cent of body weight were assumed for blood, muscle, bone and skin, respectively.

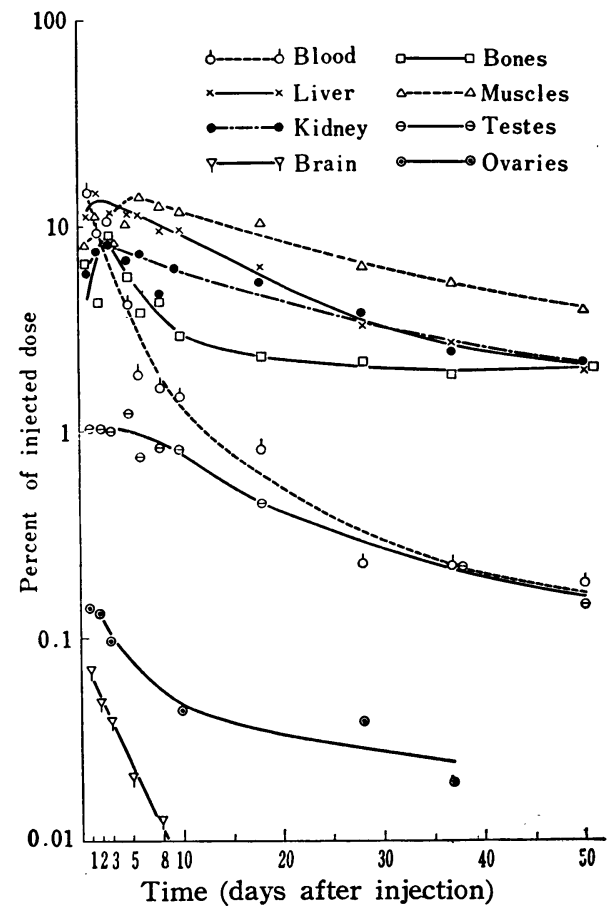

Fig. 3 Concentration of ruthenium in organs

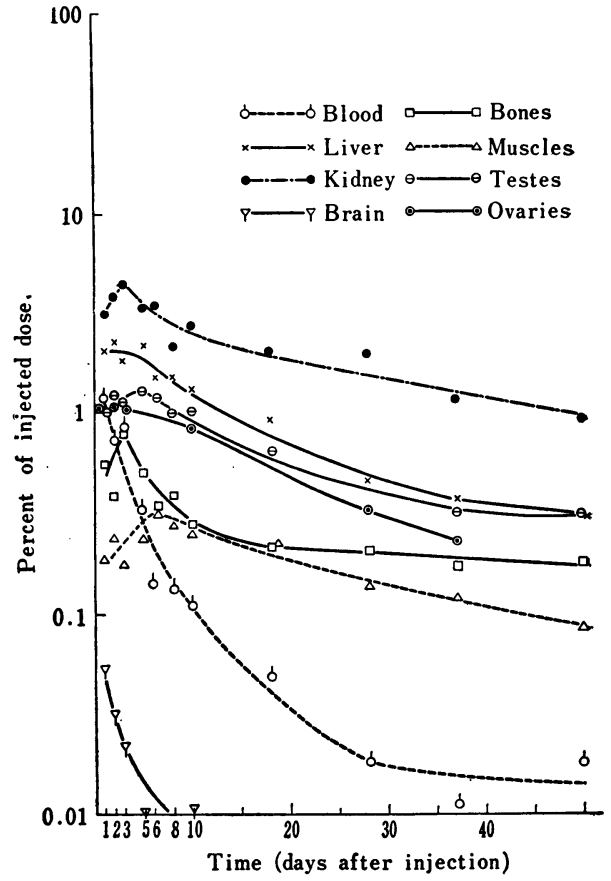

Fig. 4 Concentration of ruthenium in terms of relative specific activity (RSA) 
西連寺：マウスに括ける放射性ルテニウム $\left({ }^{106} \mathrm{Ru}\right)$ の胹器内分布扣よび排泄

Table 4 Ruthenium concentration in tissues following intraperitoneal injection

(Expressed as relative specific activity)

\begin{tabular}{|l|c|c|c|c|c|c|c|c|c|c|c|}
\hline Tissue Time & $1 \mathrm{~d}$ & $2 \mathrm{~d}$ & $3 \mathrm{~d}$ & $5 \mathrm{~d}$ & $6 \mathrm{~d}$ & $8 \mathrm{~d}$ & $10 \mathrm{~d}$ & $18 \mathrm{~d}$ & $28 \mathrm{~d}$ & $37 \mathrm{~d}$ & $50 \mathrm{~d}$ \\
\hline Blood & 1.136 & 0.740 & 0.816 & 0.329 & 0.142 & 0.130 & 0.118 & 0.049 & 0.018 & 0.012 & 0.019 \\
Spleen & 2.789 & 4.155 & 3.423 & 2.447 & 2.152 & 2.384 & 1.046 & 0.746 & 0.798 & 0.178 & 0.282 \\
Heart & 0.703 & 0.646 & 0.724 & 0.619 & 0.727 & 0.489 & 0.437 & 0.208 & 0.164 & 0.079 & 0.068 \\
Liver & 2.056 & 2.267 & 1.736 & 2.196 & 1.442 & 1.502 & 1.281 & 0.933 & 0.463 & 0.366 & 0.302 \\
Lung & 1.259 & 1.299 & 1.269 & 0.836 & 0.702 & 0.473 & 0.445 & 0.196 & 0.127 & 0.071 & 0.081 \\
Stomach & 1.863 & 2.789 & 1.345 & 0.588 & 0.852 & 0.456 & 0.391 & 0.195 & 0.109 & 0.047 & 0.043 \\
Small intestine & 2.407 & 3.060 & 2.964 & 0.882 & 1.038 & 0.983 & 0.569 & 0.243 & 0.112 & 0.033 & 0.030 \\
Pancreas & 3.025 & 7.172 & 15.795 & 3.551 & 3.232 & 2.087 & 1.993 & 1.545 & 0.372 & 0.170 & 0.159 \\
Kidney & 3.097 & 3.901 & 4.474 & 3.288 & 3.517 & 2.101 & 2.760 & 1.960 & 1.934 & 1.103 & 0.916 \\
Adrenals & 3.192 & 3.669 & 2.759 & 3.072 & 2.408 & 1.875 & 2.035 & 1.273 & 0.555 & 0.243 & 0.207 \\
Brain & 0.054 & 0.032 & 0.022 & 0.010 & 0.009 & 0.010 & 0.012 & 0.005 & 0.006 & 0.004 & 0.005 \\
Urinary bladder & 1.564 & 2.758 & 2.975 & 3.828 & 3.386 & 2.191 & 2.210 & 0.830 & 0.432 & 0.124 & 0.106 \\
Bones & 0.560 & 0.396 & 0.805 & 0.524 & 0.351 & 0.393 & 0.269 & 0.216 & 0.206 & 0.170 & 0.183 \\
Jaw bone & 0.596 & 0.524 & 0.664 & 0.385 & 0.299 & 0.251 & 0.178 & 0.192 & 0.128 & 0.161 & 0.144 \\
Teeth & 0.385 & 0.285 & 0.328 & 0.267 & 0.169 & 0.298 & 0.175 & 0.130 & 0.093 & 0.156 & 0.162 \\
Muscles & 0.187 & 0.238 & 0.178 & 0.242 & 0.306 & 0.277 & 0.255 & 0.229 & 0.135 & 0.117 & 0.085 \\
Skin and Fur & 0.322 & 0.369 & 0.323 & 0.355 & 0.415 & 0.439 & 0.478 & 0.424 & 0.514 & 0.297 & 0.190 \\
Testes & 1.093 & 1.241 & 1.126 & 1.275 & 1.187 & 1.000 & 1.025 & 0.649 & -2 & 0.308 & 0.308 \\
Ovaries & 1.101 & 1.057 & 1.142 & - & - & - & 0.865 & - & 0.331 & 0.224 & - \\
\hline
\end{tabular}

R.S. A. (Relative Specific Activity) $=\frac{\frac{\text { activity in the organ }}{\text { organ weight }(\mathrm{g})}}{\frac{\text { activity administered }}{\text { body weight }(\mathrm{g})}}$

皮膚など全身的に占める割合の大きいものおよび 内臟では肝臟, 腎臟などに多く, 投与量の数パー セントから 10 数パーセントにもおよぶ。そのほ か胃, 脾臓, 肺臟や輧丸などにも 1〜2\%の量が 存在する。中期には筋肉, 皮膚, 肝臓, 腎臓, 骨 に割合に多量に含まれている。実験後期 (37 日〜 50 日目) に扣いてもなお, 笳肉, 皮膚, 腎臓, 骨 および肝臓には投与量の約 4 ～2\% が存在してい る。放射能量の経日的な変動はいずれの臟器につ いても割合に複雑ではあるが，ほぼ指数関数的な 減少を示す数部分に分けることができる。すなわ ち, 血液, 肺臓など 2,3 のものを除いて, 最初 の 1,2 日間は徐々に放射能量が増加してゆき極 大值に達し, その後数日間は割合に急速に減少し
てゆくが次第にその傾向が緩徐になる。この状態 はとくに骨において著しい。また筋肉, 皮膚など では放射能量が最大の值になるのがほかの臟器と 比較していくぶん遅れ投与後 8～15 日目となって いる。このような所見は Scott ら ${ }^{4)}$ の報告したデ 一タからもらかがえるが, 彼らの場合, 測定用試 料の試料採取間隔が大きいために明瞭に認めては いないようである。Burykina ${ }^{17)}$ は皮下投与時に 注射部位からルテニウムは投与後 1 日目に約 50 \%が吸収されるが，そののちの吸収はきわめて 緩徐であることを確かめたが，そのさいのデータ からも, 皮膚および筋肉内へのルテニウム放射能 の集積状態について同様の傾向が認められる。

このような点から類推して投与されたルテニウ 
Table 5 Fecal and urinary excretion of ruthenium

\begin{tabular}{|c|c|c|c|c|c|c|c|}
\hline \multirow{2}{*}{$\begin{array}{c}\text { Days after } \\
\text { administration }\end{array}$} & \multicolumn{2}{|c|}{ Fecal Excretion } & \multicolumn{2}{|c|}{ Urinary Excretion } & \multicolumn{2}{|c|}{ Total Excretion } & \multirow{2}{*}{$\begin{array}{l}\text { Percent of } \\
\text { dose reta- } \\
\text { ined }\end{array}$} \\
\hline & daily & $\begin{array}{l}\text { accumula- } \\
\text { tive }\end{array}$ & daily & $\begin{array}{l}\text { accumula- } \\
\text { tive }\end{array}$ & daily & $\begin{array}{l}\text { accumula- } \\
\text { tive }\end{array}$ & \\
\hline $\begin{array}{r}1 \\
2 \\
3 \\
4 \\
5 \\
6 \\
7 \\
8 \\
9 \\
10\end{array}$ & $\begin{array}{l}0.10 \\
1.24 \\
2.69 \\
0.46 \\
2.06 \\
0.39 \\
0.89 \\
1.78 \\
0.40 \\
0.61\end{array}$ & $\begin{array}{r}\overline{1.34} \\
4.03 \\
4.49 \\
6.55 \\
6.94 \\
7.73 \\
9.61 \\
10.01 \\
10.62\end{array}$ & $\begin{array}{r}27.93 \\
6.02 \\
4.83 \\
0.65 \\
1.43 \\
0.73 \\
1.41 \\
1.16 \\
1.84 \\
0.83\end{array}$ & $\begin{array}{l}\overline{33.95} \\
38.78 \\
39.43 \\
40.86 \\
41.59 \\
43.00 \\
44.16 \\
46.00 \\
46.83\end{array}$ & $\begin{array}{r}28.03 \\
7.26 \\
7.52 \\
1.11 \\
3.49 \\
1.12 \\
2.30 \\
2.94 \\
2.24 \\
1.44\end{array}$ & $\begin{array}{l}35.29 \\
42.81 \\
43.92 \\
47.41 \\
48.53 \\
50.83 \\
53.77 \\
56.01 \\
57.45\end{array}$ & $\begin{array}{l}71.97 \\
64.71 \\
57.19 \\
56.08 \\
52.59 \\
51.47 \\
49.17 \\
46.23 \\
43.99 \\
42.55\end{array}$ \\
\hline $\begin{array}{l}11 \\
12 \\
13 \\
14 \\
15 \\
16 \\
17 \\
18 \\
19 \\
20\end{array}$ & $\begin{array}{l}0.37 \\
0.74 \\
0.31 \\
1.27 \\
0.41 \\
0.26 \\
0.28 \\
0.33 \\
0.44 \\
0.36\end{array}$ & $\begin{array}{l}10.99 \\
11.73 \\
12.04 \\
13.31 \\
13.72 \\
13.98 \\
14.26 \\
14.59 \\
15.03 \\
15.39\end{array}$ & $\begin{array}{l}0.68 \\
0.76 \\
1.69 \\
1.42 \\
0.71 \\
0.59 \\
0.63 \\
0.46 \\
0.56 \\
0.71\end{array}$ & $\begin{array}{l}47.51 \\
48.27 \\
49.96 \\
51.38 \\
52.09 \\
52.68 \\
53.31 \\
53.77 \\
54.33 \\
55.04\end{array}$ & $\begin{array}{l}1.05 \\
1.50 \\
2.00 \\
2.69 \\
1.12 \\
0.85 \\
0.91 \\
0.79 \\
1.00 \\
1.07\end{array}$ & $\begin{array}{l}58.50 \\
60.00 \\
62.00 \\
64.69 \\
65.81 \\
66.66 \\
67.57 \\
68.36 \\
69.36 \\
70.43\end{array}$ & $\begin{array}{l}41.50 \\
40.00 \\
38.00 \\
35.31 \\
34.19 \\
33.34 \\
32.43 \\
31.64 \\
30.64 \\
29.57\end{array}$ \\
\hline $\begin{array}{l}21 \\
22 \\
23 \\
24 \\
25 \\
26 \\
27 \\
28 \\
29 \\
30\end{array}$ & $\begin{array}{l}0.21 \\
0.26 \\
0.39 \\
0.74 \\
0.18 \\
0.19 \\
0.27 \\
0.15 \\
0.32 \\
0.19\end{array}$ & $\begin{array}{l}15.60 \\
15.86 \\
16.25 \\
16.99 \\
17.17 \\
17.36 \\
17.63 \\
17.78 \\
18.10 \\
18.29\end{array}$ & $\begin{array}{l}0.48 \\
0.58 \\
0.47 \\
0.51 \\
0.37 \\
0.29 \\
0.32 \\
0.19 \\
0.27 \\
0.21\end{array}$ & $\begin{array}{l}55.52 \\
56.10 \\
56.57 \\
57.08 \\
57.45 \\
57.74 \\
58.06 \\
58.25 \\
58.52 \\
58.73\end{array}$ & $\begin{array}{l}0.69 \\
0.84 \\
0.86 \\
1.25 \\
0.55 \\
0.48 \\
0.59 \\
0.34 \\
0.59 \\
0.40\end{array}$ & $\begin{array}{l}71.12 \\
71.96 \\
72.82 \\
74.07 \\
74.62 \\
75.10 \\
75.69 \\
76.03 \\
76.62 \\
77.02\end{array}$ & $\begin{array}{l}28.88 \\
28.04 \\
27.18 \\
25.93 \\
25.38 \\
24.90 \\
24.31 \\
23.97 \\
23.38 \\
22.98\end{array}$ \\
\hline $\begin{array}{l}31 \\
32 \\
33 \\
34 \\
35 \\
36 \\
37 \\
38 \\
39 \\
40\end{array}$ & $\begin{array}{l}0.15 \\
0.09 \\
0.17 \\
0.15 \\
0.20 \\
0.14 \\
0.09 \\
0.07 \\
0.12 \\
0.07\end{array}$ & $\begin{array}{l}18.44 \\
18.53 \\
18.70 \\
18.85 \\
19.05 \\
19.19 \\
19.28 \\
19.35 \\
19.47 \\
19.54\end{array}$ & $\begin{array}{l}0.15 \\
0.23 \\
0.18 \\
0.17 \\
0.09 \\
0.25 \\
0.18 \\
0.18 \\
0.11 \\
0.23\end{array}$ & $\begin{array}{l}58.88 \\
59.11 \\
59.29 \\
59.46 \\
59.55 \\
59.80 \\
59.98 \\
60.16 \\
60.27 \\
60.50\end{array}$ & $\begin{array}{l}0.30 \\
0.32 \\
0.35 \\
0.32 \\
0.29 \\
0.39 \\
0.27 \\
0.25 \\
0.23 \\
0.30\end{array}$ & $\begin{array}{l}77.32 \\
77.64 \\
77.99 \\
78.31 \\
78.60 \\
78.99 \\
79.26 \\
79.51 \\
79.74 \\
80.04\end{array}$ & $\begin{array}{l}22.68 \\
22.36 \\
22.01 \\
21.69 \\
21.40 \\
21.01 \\
20.74 \\
20.49 \\
20.26 \\
19.96\end{array}$ \\
\hline $\begin{array}{l}41 \\
42 \\
43 \\
44 \\
45 \\
46 \\
47 \\
48 \\
49\end{array}$ & $\begin{array}{l}0.14 \\
0.08 \\
0.07 \\
0.08 \\
0.11 \\
0.13 \\
0.09 \\
0.07 \\
0.08\end{array}$ & $\begin{array}{l}19.68 \\
19.76 \\
19.83 \\
19.91 \\
20.02 \\
20.15 \\
20.24 \\
20.31 \\
20.39\end{array}$ & $\begin{array}{l}0.17 \\
0.29 \\
0.08 \\
0.16 \\
0.10 \\
0.07 \\
0.09 \\
0.08 \\
0.06\end{array}$ & $\begin{array}{l}60.67 \\
60.96 \\
61.04 \\
61.20 \\
61.30 \\
61.37 \\
61.46 \\
61.54 \\
61.60\end{array}$ & $\begin{array}{l}0.31 \\
0.37 \\
0.15 \\
0.24 \\
0.21 \\
0.20 \\
0.18 \\
0.15 \\
0.14\end{array}$ & $\begin{array}{l}80.35 \\
80.72 \\
80.87 \\
81.11 \\
81.32 \\
81.52 \\
81.70 \\
81.85 \\
81.99\end{array}$ & $\begin{array}{l}19.65 \\
19.28 \\
19.13 \\
18.89 \\
18.68 \\
18.48 \\
18.30 \\
18.15 \\
18.01\end{array}$ \\
\hline
\end{tabular}

All values are expressed in per cent of administered dose

ムの腹腔内から血液中への移動は，まず投与され た総量中の相当の部分がはいるが，その残りの部 分は割合に遅い速度で移ってゆくものであり，ま
た血液とほかの臓器との間における交換もそれほ ど早くはないと考えうる。またこのような全身に 存在する臟器組織への一様な分配状態およびその 
西連寺：マウスに打ける放射性ルテニウム $\left({ }^{106} \mathrm{Ru}\right)$ の䁍器内分布和よび排泄

減衰速度のおそさからこの核種による全身的な 内部照射という問題も考えておく必要があろう。

臟器内のルテニウム濃度を RSA 值によってみ ると, 一般に全身的に存在する臟器組織中の值は $1 よ り$ 低いが, 腹部臟器には高い值をとるものが 多く, 副腎, 腎臟, 膵臟, 肝臓ならびに脾臓など はほぼ 3 であり，ことに膵臓は 3 日目に異常に高 い約 16 という值を示した。そのほか, 鋅丸, 卵 巣などの生殖腺も投与後 10 日目ぐらいまで 1 内 外の值であった。腎臟における值は, 実験期間中 をとおしてほかの臟器のものに比して高く, ほか の研究者もいうように注意す心゙き臟器 (critical organ) であるとしてょいと考える。そのほか, 肝藏, 睪丸, 副腎, 脾藏, 膵臓なども注射後 50 日目に㧍いてもなお約 0.2 の值をしめしている。 吉川ら ${ }^{11)} 10$ 日ほどの実験期間中の結果でマウ ス腹腔内投与時のルテニウムが歯，骨に多く，次 いで腎臟に多いとしているが著者の結果ではとく にその傾向は認められなかった。しかし，骨の RSA 值は実験の後期においても上記の諸藏器に 匹敵するものであり，その減少速度が遅いことと あわせて考えて注意すべき臟器と考えることがよ いと思われる。

3）ルテニウムの排泄

毎日の尿および糞中に排泄されたルテニウムの 放射能量を投与量に対する百分率であらわしたも のおよびこの 2 つを合計して 1 日あたりの体内か らの総排泄量としたものを第 5 表に示した。生物 体内から放射性物質が排泄されるおもな経路は 尿，糞，呼気および汗によるものであるが，この うちあとの $2 つ$ はの割合が小さいと思われるか

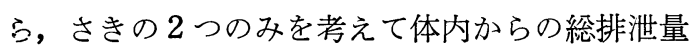
とした。また体内に残存するルテニウムの放射能 量は投与量から排泄された全量を差引いたもので あるから, 総排泄量の積算值を求めてそれによっ て毎日の体内残存量を算出した。

第 5 図は毎日のルテニウムの排泄量の変化をあ らわしたものであり，その值にかなりの変動はあ るが，大体指数関数的な減少の傾向であるとして
Fig. 5 Daily excretion of intraperitoneal injected ruthenium.

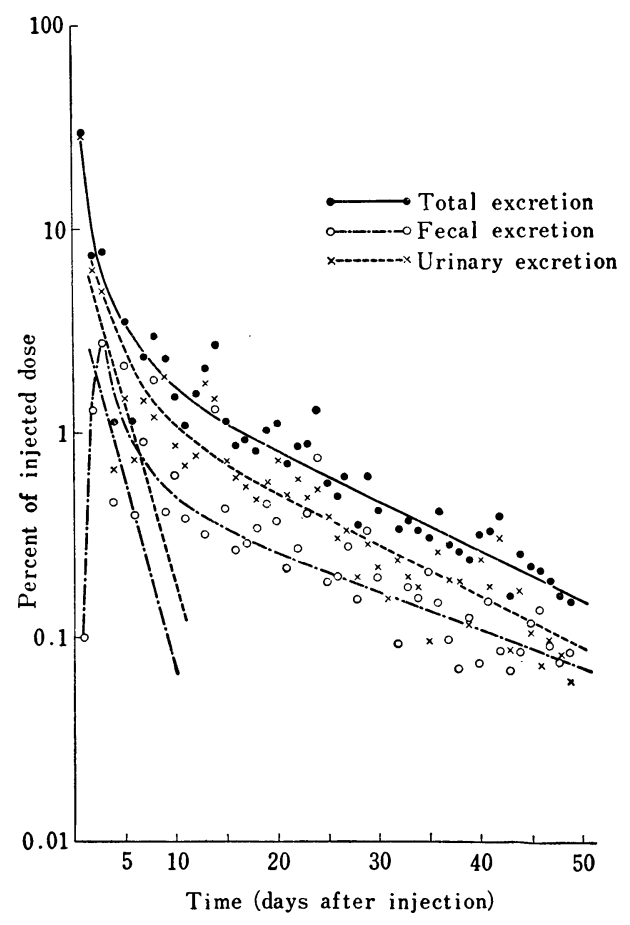

よい。すなわち, 実験の初期の 10 日間において は尿中へのものおよび粪中へのもののいずれにお いてもかなり急激な量の減少が認められ $\left(\mathrm{T}_{1 / 2}=\right.$ 約 2 日）それ以後はゆるやかな傾斜で減少し排泄 速度がおそくなっている。(尿中へのもの $\mathrm{T}_{1 / 2}=$ 約 12 日, 糞中へのもの $\mathrm{T}_{1 / 2}=$ 約 16 日）ただし, 粪 中への排泄をみると投与直後の 2 日間は次第に増 加し 3 日目に最高值となっており，そののちは上 に述べた減少の傾向をとるが，これは腹腔内に投 与されたルテニウムが血液にとり込まれ, さらに 肝臓, 膵臓などに集められ排泄される速度が遅い ことを示すものと考えられる。また毎日あたりの 体内からの総排泄量についても同様の傾向がみら れる。

実験開始後 2 週間で投与量の約 $65 \%$ が排泄さ れ，尿中への量と糞中への量との比はほぼ $4: 1$ （尿中へ約 $50 \%$ ，粪中へ約 15\%) である。実験終 了までの総排泄量は尿，糞およびその合計につい 
てそれぞれ投与量の $60 \%, 20 \%$ および $80 \%$ で あった。また尿中への量と糞中への量の比は $3: 1$ となった。

この排泄の傾向は Scott ら4)のものとよく一致 しているが，排泄の総量は著者の実験における方 が幾分多い。また，Burykina ${ }^{17)}$ の皮下投与の実 験, Bair ${ }^{18)}$ の吸入による実験のそれとも類似した 傾向の排泄型をしめしていた。これらのことから 体内にはいったルテニウム排泄の主要経路は腎藏 をとおして尿中へなされるものであるといいう る。

4）生物学的半減期および有効半減期

生物体あるいは 1 つの臟器中から放射性物質が 減少してゆく割合は簡単な指数関数として近似的 にあらわされるので，あたかも放射能の物理学的 減衰と同様に扳り扱って, その生物学的半減期を 求めることができる。第 6 図は体内に残存してい るルテニウム放射能の時間経過に対応する変化の 状態をあらわしたもので, この曲線の解析から 3 つの直線部分に分解でき, 生物学的半減期がそれ ぞれ約 1 日， 8 日および 100 日程度と求ま る。体内にはいった放射性核種は実際には その物理的半減期および生物学的半減期の 双方によって減少するが，それを有効半減 期 $\left(\mathrm{T}_{\text {eff }}\right)$ といい，次式によって算出され る。 $\quad \mathrm{T}_{\text {eff }}=\frac{\mathrm{T}_{p} \times \mathrm{T}_{b}}{\mathrm{~T}_{p}+\mathrm{I}_{b}}$

ここに $\mathrm{T}_{p}$ はその核種の物理的半減期,

$\mathrm{T}_{b}$ は生物学的半減期である。これによっ て全身に対する ${ }^{106} \mathrm{Ru}$ の有効半減期はそれ ぞれ 1, 7.6, 78.5 日と求められる。そして 曲線の解析からえたそれぞれの部分の占め る割合は $30 \% ， 45 \%$ および $25 \%$ 程度で あった。同様にして求めた主要な各臓器の 生物学的半減期および有効半減期を ICRP 勧告 ${ }^{35)}$ の值とともに第 6 表に示めした。

これによって ${ }^{106} \mathrm{Ru}$ の生物学的半減期が 全身，腎臓および骨について勧告中の值よ りもかなり大きく，ことに全身については 100 日の部分が投与量の $25 \%$ にも及んで
おり，骨中にはいった約 $2 \%$ の部分（骨自体に対 する量としては $28 \%$ 程度）が 150 日の長い半減

Fig. 6 Retention of ruthenium activity in the animal

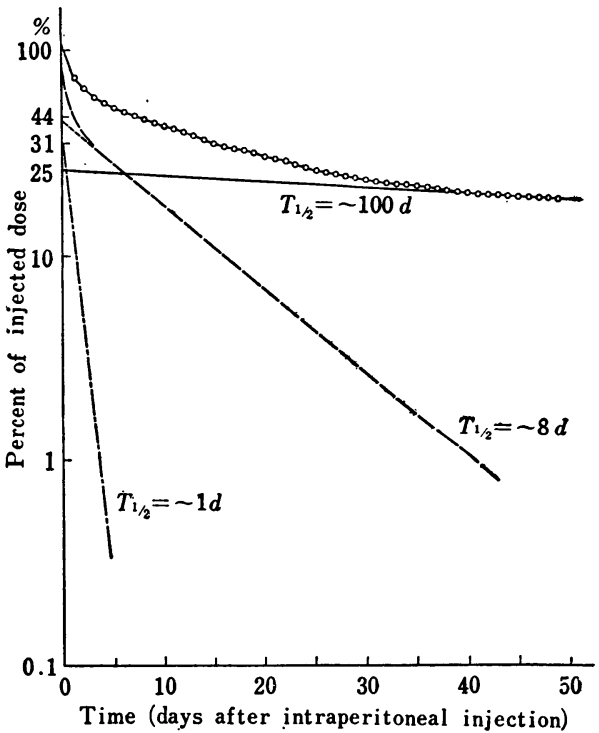

Table 6 Biological and effective half-life of ruthenium-106 in various tissues

\begin{tabular}{|c|c|c|c|}
\hline & Biologica & $\begin{array}{c}\text { half-life } \\
\text { (days) }\end{array}$ & 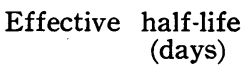 \\
\hline Blood & 2, & 21 & 19.9 \\
\hline Spleen & \multicolumn{2}{|c|}{8} & 7.6 \\
\hline Lung & 2 , & 17 & 16.2 \\
\hline Liver & 6 , & 30 & 27.7 \\
\hline Kidney & \multicolumn{2}{|c|}{24} & 22.5 \\
\hline Brain & 2, & 22 & 20.7 \\
\hline Bones & 2 & 150 & 2.0 \\
\hline Muscles & 13, & 20 & 12.6, \\
\hline Skin and Fur & \multirow{2}{*}{\multicolumn{2}{|c|}{$\begin{array}{l}25 \\
18\end{array}$}} & \multirow{2}{*}{$\begin{array}{l}23.4 \\
17.2\end{array}$} \\
\hline Testes & & & \\
\hline Ovaries & 2 , & 25 & 23.4 \\
\hline Total body & & 8,100 & $1, \quad 7.6,78.5$ \\
\hline \multicolumn{4}{|c|}{ Recommendation of I.C. R.P. (1959) } \\
\hline Bone & \multicolumn{2}{|c|}{16} & 15 \\
\hline Kidney & \multicolumn{2}{|r|}{2.5} & 2.48 \\
\hline Total body & \multicolumn{2}{|r|}{7.3} & 7.2 \\
\hline
\end{tabular}


西連寺：マウスに扱ける放射性ルテニウム $\left({ }^{106} \mathrm{Ru}\right)$ の臟器内分布扣よび排泄

期で減衰していることは注目に值する。

K. T. Woodward ら ${ }^{37}$ はマウスに ${ }^{134} \mathrm{Cs}$ を投与 した場合の全身についての生物学的半減期を 0.5 , 2.4 および 6.6 日と求め, これらのそれぞれが血管 系, 筋肉系抢よびそのほかの軟組織からの ${ }^{134} \mathrm{Cs}$ の消失に対応するものとしている。けれども本実 験においてはそのように明瞭な対応を認るめこと はできなかった。これはさきにも述べたようにル テニウムの生体内における移動が緩やかであり, かつ，割合に複雑であることに起因するものと考 えられる。

\section{要 約}

1) ${ }^{106} \mathrm{Ru}+{ }^{106} \mathrm{Rh}$ の $0.48 \mu \mathrm{c}$ をマウ.ス腹腔内に 注射し経日的に体内の放射能分布および排泄をし らべた。投与したトレーサー溶液中にはルテニウ ムのラジオコロイドの生成は認められず，また口 紙電気泳動によって $\left[\mathrm{RuCl}_{5}\left(\mathrm{H}_{2} \mathrm{O}\right)\right]^{-2}, 〔 \mathrm{RuCl}_{4}$ $\left.\left(\mathrm{H}_{2} \mathrm{O}\right)_{2}\right]^{-1}$ および $\left[\mathrm{RuCl}_{3}\left(\mathrm{H}_{2} \mathrm{O}\right)_{3}\right]^{0}$ などのイオン 種の存在が推定された。

2) 投与後 1 日目の血液中に打ける ${ }^{106} \mathrm{Ru}$ はそ の約 $93 \%$ が血漿中にあり，口紙電気泳動によっ て蛋白の分画を拉こなうと, アルブミン， $\beta$-グロ ブリンおよび $\gamma$-グロブリン相当部分にそれぞれ $52 \%, 34 \%$ および $14 \%$ 程度の放射能が認められ る。

3) ‘投与されたルテニウムは臟器全量について は実験開始後 10 日目頃までは血液, 骨, 筋肉, 皮膚など全身における存在量の大きいものおよび 肝臓, 腎臓などに多く, 投与量の 10 数パーセン トないしは数パーセント程度である。中期におい てもやはり筋肉, 皮膚, 肝臟, 腎臟, 骨などに多 くみられ，この傾向は本実験の終了に至るまで同 様であった。

4) 臓器内への濃縮度は一般に腹部臟器に高い 值を示すものが多く, 副腎, 腎臓, 膵臓, 肝臓な らびに脾藏などに濃縮が著しい。ことに腎臓は実 験の全期間を通じて高い值を示した。冝丸，卵单 などの生殖腺も比較的大きい值をとっている。筋
肉, 皮膚, 骨などはそれほど高い值を示してはい ない。

5）ルテニウムの尿および糞中への排泄は, 最 初の 2 週間以内が急激で投与量の約 $65 \%$ (尿; 約 $50 \%$ ，糞；約 15\%）が出される。本実験の終了ま での総排泄量は投与量の約 $80 \%$ (尿；約 $60 \%$, 粪; 約 20\%) であり，つ称に尿中への排泄が粪中 へのものよりも相当大きい割合で約 3〜4 倍程度 であった。これは体内からのルテニウム排泄の主 要系路が，腎臓をとおって尿中へ出されるもので あることを示す。

6) 体内のルテニウムの残存量を算出して, そ れによりルテニウムの生物学的半減期と ${ }^{106} \mathrm{Ru} の$ 有効半減期を求め, それぞれ $1,8,100$ 日および 1,7.6, 78.5 日をえた。またそれらの半減期の部分 が占める割合はおのおの $30 \%, 45 \%$ および $25 \%$ 程度である。そのほかの臟器についても同様の解 析をして生物学的半減期と有効半減期を求めてあ る。このうち腎臟では 24 日および 22.5 日，骨 では 2 日，150日および 2.0 日，106 日（骨中に おける総量の約 $28 \%$ に当る部分) であった。こ れらの值はいずれも ICRP 勧告のものに比べて かなり長い部分を含んでいる。

終りに本研究の実施にあたり終始ご指導とご激 励をたまわった日本大学歯学部長鈴木勝教授に深 く感謝申し上げます。また実験に関して種々有益 なご助言をいただいた東京大学理学部斉藤信房教 授ならびに東京教育大学理学部池田長生助教授, 本稿のご校閲をたまわった日本大学医学部森信胤 教授に厚くお礼申し上げます。本実験にたいして は本研究室の鈴木智哲氏, 大附敏海氏その他の方 々のご助力を得た。また要した費用の一部は文部 省科学研究費より支出した。記して感謝の意を表 する。

\section{交献}

1) J. G. Hamilton: $M D D C-490$ (1946).

2) J.G. Hamilton: $M D D C-1001$ (1947). 
3) J. G. Hamilton: $M D D C-1062$ (1947).

4) K. G. Scott, R. Overstreet, L. Jacobson, J. G. Hamilton, H. Fischer, J. Crowley, I. L. Chaikoff, C. Entenman, M. Fischer, A. J. Barber, and F. Loomis; $M D D C-1275$ (1947).

5) J. G. Hamilton: $M D D C-1160$ (1947).

6) J.G. Hamilton: Radiology, 49, 325 (1947).

7) J.G. Hamilton: Rev.Mod. Phys., 20, 718 (1948).

8) J.G. Hamilton: New. Engl. J.Med., 240, 863 (1949).

9) 吉沢康雄, 亘理勉：アイットープ研究利用総覧， B-39, P. 474 (1956).

10）入江英雄, 策原慎治：アイットープ研究利用総覽， B-38, P. 471 (1956).

11）吉川春寿, 島薗順雄, 江藤秀雄, 三浦義彰, 佐藤 徳郎，筧弘毅：第 1 回原子カシンポジウム報交集, C-29, p. 794 (1957).

12）宮川正, 江藤秀雄, 亘理勉, 吉沢康雄：第 1 回原 子カシンポジウム報文集，C-30, p. 796 (1957).

13) S. Katcoff: Nucleonics, 16, 78 (1958).

14) H.F. Hunter and N.E.Ballou: Nucleonics, 9, C-2 (1951).

15) R.C. Thompson and O.L. Hollis: $H W-35917$, p. 82 (1955).

16) M.H.Weeks and R.C. Thompson: $H W-35917$, p. 74 (1955).

17) L. N. Burykina: $A E C$-tr-3794, p. 46 (1957).

18) W. J. Bair, L.A. Temple and D. H. Willard: $H W-53500$, p. 143 (1957).

19) W. J. Bair, L. A. Temple, J. L. Terry and A. Graybeal: $H W-52285$ (1957).

20) D. H.Willard, L.A. Temple and W. J. Bair: $H W-52286$ (1957).
21）斉藤信房, 池田長生, 西連寺永康, 千葉盛人：交 部省研究報告集録（昭 32）放射編 p. 156 (1958).

22）斉藤信房, 池田長生, 西連寺永康：交部省研究報 告集録（昭 32）放射線編 p. 157 (1958).

23）木村健二郎, 池田長生, 川西はる子：Radioisotopes, 4, 28 (1956).

24）塩川孝信, 八木益男：日本化学会講演（1956 年 4 月) 京都

25) A.E. Martell and M.Calvin: Chemistry of metal chelate compounds, 3rd. Ed., p. 247, Englewood Cliffs, N. J., Prentice-Hall Inc., (1956).

26) 松浦二郎：西川勝：第 4 回放射化学討論会要旨集 p. 17 (1960).

27) J. Schubert and E. E. Covn: Nucleonics, 4, (6) 2 (1949).

28) Report of Joint WHO/FAD Expert Committee on Radiochemical Methods of Analysis (Geneva, 15 to 20 Sept. 1958) p. 48.

29) E. E. Foreman: $R$ and $D B(W) T N-106$ (1959).

30) R.F.Palmer: $H W-35917$, p. 68 (1955).

31）小林茂三郎, 村井京子, 大野育男, 山本宏, 中井 川明, 鈴木恒子, 小島津彥, 五味淵秀夫, 落合清 治：日大医学雑誌，15, 2301, (1956).

32) L.D. Marinelli, E. H. Quimby and G. J. Hine: Nucleonics, 2, (5) 44 (1948); 2, (4) 55 (1948)

33）渡辺勲；日本医放会誌，19, 1303 (1959)

34）筧弘毅, 渡边勲, 三宅仁, 营野晴夫; 日本医放会 誌, 19, 1688 (1959)

35) Report of ICRP Committee II on Permmissible Dose for Internal Radiation, (1959): Health Physics, 3, (1960)

36) K. T. Woodward, C. R. Richmond and Laugham: Proc. Health Phys. Soc., 79 (1956) 


\title{
Tracer Studies on the Distribution and Excretion of Radioactive Ruthenium ( ${ }^{106} \mathrm{Ru}$ ) in Mice
}

\author{
By \\ Eiko SAIRENJI \\ (Dept. of Radiology and Radioisotope Research Lab., Nihon Univ., School of Dentistry)
}

(Received October 20, 1960)

In order to obtain biological data for the metabolism of radioactive ruthenium, the distribution and excretion of ruthenium in mice were studied at various intervals following an intraperitoneal injection of $0.48 \mu \mathrm{c}$ of the tracer ${ }^{106} \mathrm{Ru}\left(+{ }^{106} \mathrm{Rh}\right)$ solution.

By means of paper electrophoresis, prior to this experiment, the ion species of ruthenium and their proportion in the tracer solution were ascertained as is shown in Fig. 1 and Table 2. Centrifugal separation of the same solution did not show any formation of radiocolloid.

It was found that approximately 93 per cent of the radioactivity in the blood of mice, one day after injection, existed in the blood plasma. Electrophoretic separation of this plasma indicated that about 52 per cent of ruthenium activity was found in the albumin fraction, 34 per cent in the $\beta$-globulin and 14 per cent in the $\gamma$-globulin. (Fig. 2)

The contents of ruthenium activity in the various organs, expressed in per cent of the amount introduced, are shown in Table 3 and Fig.3. In the first 10 days of this experiment, the large portion of the remaining ruthenium activity was found in the blood, bone, muscle, skin and fur, liver and kidneys. The amounts ranged from 2 or 3 per cent to about 13 or 14 per cent of the injected activity. Thereafter, the ruthenium content gradually decreased until the end of this 50 days experiment, with the exception of blood. Blood showed a comparatively high elimination rate.

The concentrations of injected ruthenium within various organs at autopsy are shown in Table 4 and Fig. 4 in terms of Relative Specific Activity (RSA). From the results, it was found that high concentrations existed in the abdominal organs such as the adrenals, kidneys, pancreas, liver and spleen etc., a slightly lower level existed in the genital organs. Still lower concentrations were found within the muscle, skin and bone. The ruthenium activity in the kidneys remained relatively high during the whole period of this experiment.

The daily excretion of injected ruthenium was quite high during the first 2 weeks of this experiment, and, thereafter, it became relatively slow. About 80 per cent (urinary $60 \%$, fecal $20 \%$ ) of the injected ${ }^{106} \mathrm{Ru}$ was excreted by the end of this experiment. The excretion rate via urine was 3 to 4 times that via feces. (Table 5 and Fig. 5) 
The total body elimination rate of injected ${ }^{106} \mathrm{Ru}$ is shown in Fig. 6. The turnover curve was resolved into three exponential components having biological half-lives of 1,8 and 100 days, respectively. The 1 day half-life component accounted for 30 per cent of the injected amount, the 8 day half-life component accounted for 45 per cent, and 25 per cent had a half-life of 100 days.

The biological and effective half-lives for the other organs were also tabulated in Table 6. Comparing the figures in this table with the data given by the ICRP recommendation in 1959, it is apparent that the longer half-life components of ruthenium seem to stay in bones and kidneys.

These results show that the hazards of internal irradiation by radioactive ruthenium should be emphasized. 